\title{
Enzyme-linked immunosorbent assay with a Salmonella enteritidis antigen for differentiating infected from vaccinated poultry
}

\author{
Cristina Solano ${ }^{\mathrm{a}}$, Julia Galindo ${ }^{\mathrm{b}}$, Begoña Sesma ${ }^{\mathrm{b}}$, \\ Miguel Alvarez ${ }^{c}$, María J. Solsona ${ }^{\mathrm{d}}$, Carlos Gamazo ${ }^{\mathrm{a} *}$ \\ ${ }^{a}$ Departmento de Microbiología, Universidad de Navarra, 31080 Pamplona, Spain \\ ${ }^{\mathrm{b}}$ Instituto de Salud Pública de Navarra, 31004 Pamplona, Spain \\ ${ }^{\mathrm{c}}$ Laboratorio Municipal, 31004 Pamplona, Spain \\ ${ }^{\mathrm{d}}$ CESAC, Reus, Spain
}

(Received 20 January 2000; accepted 18 May 2000)

\begin{abstract}
The specificity and sensitivity of indirect ELISA, based on the use of four different antigenic extracts obtained from a clinical isolate of Salmonella enteritidis, were compared with those obtained with the gm-flagellin based ELISA (IDEXX). A total of 116 serum samples from salmonellae free, naturally infected and vaccinated hens were studied. The results showed that the indirect ELISA, based on lipopolysaccharide (LPS), O-polysaccharide (PS) or membrane sediment (SD) antigens, enable the identification of a greater number of infected birds and discriminated field antibody responses from vaccinal ones better than the commercial IDEXX test. The indirect ELISA that used a O-polysaccharide rich fraction (PS) proved to be the most specific and sensitive test, suggesting that this indirect ELISA could be used to confirm IDEXX results, especially when the differentiation between vaccinated and infected poultry is required.
\end{abstract}

Salmonella / serological diagnosis / poultry / ELISA

Résumé - ELISA basé sur l'utilisation d'un antigène de Salmonella enteritidis pour la différentiation entre la volaille infectée et vaccinée. La spécificité et la sensibilité d'une nouvelle méthode ELISA indirecte, basée sur l'utilisation de quatre extraits antigéniques différents obtenus d'un isolat clinique de Salmonella enteritidis, ont été comparées avec celles d'un autre ELISA basé sur l'utilisation de la gm-flagelline (IDEXX). Un total de 116 échantillons de sérum provenant de poules saines (non-infectées avec Salmonella), infectées ou vaccinées, a été analysé par les deux techniques. Les résultats ont clairement démontré que la méthode ELISA indirecte, utilisant les antigènes LPS, une fraction riche en polysaccharide-O (PS) ou le sédiment de membranes SD (LPS-proteins complex), permettait l'identification d'un plus grand nombre d'animaux infectés, et une meilleure différentiation

* Correspondence and reprints

Tel.: (34) 948 425688; fax: (34) 948 425649; e-mail: cgamazo@unav.es 
entre les poules infectées et les poules vaccinées que le test commercial IDEXX. La méthode ELISA utilisant la fraction polysaccharidique-O (PS) s'est révélée être le test de diagnostic sérologique le plus spécifique et le plus sensible. Ces résultats suggèrent que cet ELISA peut être utilisé pour la confirmation des résultats obtenus par le test IDEXX, notamment quand la différentiation entre la volaille vaccinée et non-vaccinée est nécessaire.

Salmonella / diagnostic sérologique / volaille / ELISA

\section{INTRODUCTION}

Salmonella enteritidis is recognised as a frequent and important pathogen for poultry and has been isolated from broiler, breeder and commercial egg laying flocks [1, 19]. Both poultry meat and eggs are often mentioned to cause salmonellosis in man [26]. Monitoring flocks for $S$. enteritidis infection is typically accomplished via bacteriological or serological methods. Bacteriological examination for the detection of flock infections on a practical basis is laborious, time-consuming, and expensive, especially when a statistically reliable number of faecal samples per flock is tested to confirm that a flock found bacteriologically negative for $S$. enteritidis is truly free of S. enteritidis [11]. Bacteriological examination may also yield false negative results when S. enteritidis is overgrown by other Salmonella serotypes present in the flock [28]. Identification of infected birds is also difficult because $S$. enteritidis can induce a chronic carrier state, whereby apparently healthy birds excrete the organisms intermittently [31].

For these reasons, many authors have pointed out the need for a suitable serological assay for use as a screening technique to detect $S$. enteritidis infection in poultry $[2,3$, 14, 20, 21, 27]. Many techniques for the serological identification of infected flocks have been described; these include agglutination tests (rapid whole blood slide test, tube agglutination test, and antiglobulin test) and enzyme-linked immunosorbent assays (ELISAs) with different antigens, such as lipopolysaccharide (LPS), SEF 14 fimbrial antigen, flagellin, outer membrane proteins, and crude extracts (obtained by heat treatment) of S. enteritidis [4, 6-10, 12, 15-17, 21, 23-25].

The use of vaccines for the control of Salmonella infections is gradually increasing [33] but it interferes with serological screening, since conventional tests cannot discriminate vaccinal antibody responses from natural infection. This paper evaluates the specificity, sensitivity and discrimination capacity of an indirect ELISA based on the use of four different antigens obtained from a clinical isolate of $S$. enteritidis, and compares the results to those obtained with the gm-flagellin based ELISA implemented in the Dutch $S$. enteritidis eradication program $[27,28]$, for detecting infection in naturally infected chickens.

\section{MATERIALS AND METHODS}

\subsection{Serum samples}

A total of 116 serum samples from reproductive hens (7-11 months old) were studied. Serum samples in group $1(n=72)$ were obtained from $S$. enteritidis naturally infected hens as confirmed by rectal swab culture. Serum samples in group $2(n=22)$ were taken from salmonellae free hens and samples in group $3(n=22)$ were taken from hens vaccinated at the age of 4 months ( $S$. enteritidis commercial bacterine; Laboratorios Hypra, Gerona, Spain).

Positive and negative control serum sample pools were prepared by pooling ten individual serum from infected hens and ten 
individual serum from salmonellae free hens respectively.

\subsection{Preparation of ELISA antigenic extracts}

Antigenic extracts were prepared from $S$. enteritidis 4520 , a clinical isolate obtained from Ramon Díaz, Microbiology Department of the Clínica Universitaria de Navarra (Pamplona, Spain). S. enteritidis 4250 was incubated in Trypticase Soya Broth (TSB, BioMérieux) pH 7.2, at $37{ }^{\circ} \mathrm{C}$ up to the exponential phase $\left(\mathrm{OD}_{590}=0.4\right)$. Cells were then inactivated by addition of phenol (final concentration, $0.5 \%$ ), washed with saline solution and centrifuged at $4000 \mathrm{~g}$ for $20 \mathrm{~min}$. The supernatant was harvested and ultracentrifuged (100000 g, 6 h), then the sediment (SD) and supernatant (SS) were collected and lyophilised. A crude lipopolysaccharide extract (LPS) was obtained from the harvested cells after the first centrifugation by the hot water-phenol method of Westphal et al. [30]. An Opolysaccharide rich fraction (PS) was obtained from the extracted LPS by resuspending it in $2 \%$ acetic acid ( $2 \mathrm{mg}$ of dried weight $\cdot \mathrm{mL}^{-1}$ ) and hydrolysing it at $100{ }^{\circ} \mathrm{C}$ for $1 \mathrm{~h}$. After centrifugation $(100000 \mathrm{~g}, 6 \mathrm{~h})$ the supernatant was dialysed for 2 days at $4{ }^{\circ} \mathrm{C}$ against several changes of distilled, deionised water, and lyophilised.

The protein and LPS contents of these four antigenic preparations were measured by the Lowry [18] and ketodesoxyoctonate (KDO) assays [22, 29], respectively.

\subsection{Bacteriological examination}

Reproductive hens were bacteriologically examined for the presence of salmonellae by incubation of rectal swabs in enrichment media (Rappaport Vassiliadis and Selenite Cystine broth) followed by inoculation of Xylose Lysine Agar (XLD) and Salmonella Shigella Agar (SS).

\subsection{Determination of positive/negative cut-off value}

A total of 22 serum samples from Salmonella-free birds were examined by ELISA using four different antigen extracts (SS, SD, LPS, PS). The cut-off point for the antigens was selected as the mean plus two standard deviations in order to prevent the detection of false positives. The dilution of sera was $1 / 1000$.

\subsection{ELISA procedure}

IDEXX test - The gm-flagellin based ELISA (IDEXX) procedure was carried out as described by the manufacturer (cut off value $\mathrm{C} / \mathrm{N}$ : 0.75 ) (Idexx laboratories, Inc., Westbrook, Maine, USA).

Indirect ELISA — The following conditions were determined in preliminary experiments: Polystyrene microtitre plates (Bioreba, Spain) were coated with $50 \mu \mathrm{L}$ of their respective antigenic extract solutions $\left(5 \mu \mathrm{g} \cdot \mathrm{mL}^{-1}\right)$ in coating buffer $(0.05 \mathrm{M}$ carbonate/bicarbonate buffer, $\mathrm{pH}$ 9.6) and incubated at $4{ }^{\circ} \mathrm{C}$ for $12 \mathrm{~h}$. The solution was then tipped off and the microplates were washed three times in PBST (PBS plus $0.05 \%$ Tween 20). Then, $50 \mu \mathrm{L}$ of test and control sera diluted 1/100 and 1/1000 in PBS Tween buffer containing 5\% skimmed milk were added per well. The plates were then incubated for $4 \mathrm{~h}$ at $37^{\circ} \mathrm{C}$ and washed as before. A solution of peroxidase conjugated to goat anti-chicken IgG (Nordic Labs, Tilburg, The Netherlands), diluted $1 / 5000$ in PBS containing $0.05 \%$ Tween 20 , was added in $50 \mu \mathrm{L}$ volumes to each well. The conjugate was incubated for $30 \mathrm{~min}$ at $37^{\circ} \mathrm{C}$ and washed. Finally, plates were developed by incubation for $20 \mathrm{~min}$ at room temperature with 2,2'-azino-bis-3-ethylbenzothiazoline6-sulphonic acid diammonium salt $0.01 \%$ (Sigma) in $0.1 \mathrm{M}$ citrate buffer ( $\mathrm{pH} 4.0)$ containing hydrogen peroxide $0.01 \%$. The colorimetric values were determined by measuring the OD at $405 \mathrm{~nm}$. 
The percentage specificity and sensitivity of IDEXX and indirect ELISA based on the four antigenic extracts, were calculated with the Episcope 1.0 software (Agriculture University, Wageningen, the Netherlands) with a $95 \%$ confidence level.

\section{RESULTS}

\subsection{Chemical characterisation of the antigenic extracts}

Table I shows the percentage of proteins/LPS of the four antigenic extracts used in this study, obtained from $S$. enteritidis

Table I. Percentage of proteins/LPS of the four antigens obtained from Salmonella enteritidis 4520 .

\begin{tabular}{lc}
\hline Antigen $^{\mathrm{a}}$ & Prot/LPS \\
\hline LPS & $1.3 / 99.0$ \\
PS & $0.6 / 17.9$ \\
SD & $31.6 / 50.7$ \\
SS & $23.8 / 27.9$
\end{tabular}

a LPS, lipopolysaccharide; PS, O-polysaccharide rich fraction; SD, membrane sediment fraction; SS, soluble fraction.
4520. The protein contamination of the LPS fraction was only $1.3 \%$. The polysaccharide extract (PS) contained LPS (17.9\%) and a trace of proteins. SD and SS antigenic preparations were the richest in proteins.

\subsection{Comparison between IDEXX test and ELISA using different $S$. enteritidis antigenic extracts}

First, the cut-off points were established, in order to determine the sensitivity and specificity of the indirect ELISA using the different antigenic extracts. These were selected as the mean plus two standard deviations, after studying a total of 22 serum samples from Salmonella-free birds, by indirect ELISA. The cut-off points were as follows: $\mathrm{OD}_{405 \mathrm{~nm}}$ LPS, 0.559; PS, 0.336; SD, 0.557 ; SS, 0.401 .

Table II shows the mean $\mathrm{OD}_{405 \mathrm{~nm}}$ registered for each sample group after being examined by indirect ELISA and the commercial IDEXX test. Serum samples in group $1(n=72)$, which were obtained from S. enteritidis infected hens, as confirmed by rectal swab culture, presented a more variable response when examined by IDEXX than when examined with LPS, PS or SD antigens.

Table II. ELISA comparative results (mean $\mathrm{OD}_{405 \mathrm{~nm}}$; $\mathrm{SD}$ ) using the four different antigenic extracts for each serum sample group (serum dilution 1/1000).

\begin{tabular}{lcccccc}
\hline Group $^{\mathrm{a}}$ & $n^{\mathrm{b}}$ & IDEXX & $\begin{array}{c}\text { LPS } \\
{[0.559]^{\mathrm{c}}}\end{array}$ & $\begin{array}{c}\text { PS } \\
{[0.336]}\end{array}$ & $\begin{array}{c}\text { SD } \\
{[0.557]}\end{array}$ & $\begin{array}{c}\text { SS } \\
{[0.401]}\end{array}$ \\
\hline 1 & & & & & & \\
1 & 40 & + & $0.946(0.590)$ & $0.752(0.610)$ & $0.906(0.282)$ & $0.460(0.274)$ \\
1 & 16 & - & $0.799(0.106)$ & $0.640(0.352)$ & $0.642(0.255)$ & $0.444(0.208)$ \\
2 & 16 & $+/-$ & $0.676(0.127)$ & $0.471(0.425)$ & $0.494(0.360)$ & $0.392(0.225)$ \\
3 & 22 & - & $0.245(0.157)$ & $0.178(0.790)$ & $0.333(0.112)$ & $0.253(0.740)$ \\
& 22 & + & $0.792(0.257)$ & $0.536(0.270)$ & $0.970(0.164)$ & $0.370(0.125)$ \\
\hline
\end{tabular}

${ }^{\text {a }}$ Groups: 1, naturally infected with $S$. enteritidis (this group was divided in three depending on the IDEXX results, positive, negative or intermediate, for a cut off value of 0.75 ); 2 , Salmonella free; 3 , vaccinated with a commercial bacterine of $S$. enteritidis.

${ }^{\mathrm{b}}$ Number of serum samples.

${ }^{\mathrm{c}}$ Cut off values. 
Table III. Comparative values of sensitivity and specificity (\%) of IDEXX and indirect ELISA (four different antigenic extracts).

\begin{tabular}{|c|c|c|c|c|c|}
\hline & & Sensitivity $^{\mathrm{a}}$ & Specificity $^{\mathrm{a}}$ & Sensitivity ${ }^{\mathrm{b}}$ & Specificityb \\
\hline Indirect & LPS & 70.8 & 100 & 70.8 & 59.9 \\
\hline \multirow{3}{*}{ ELISA } & PS & 76.4 & 100 & 76.4 & 88.6 \\
\hline & SD & 72.2 & 100 & 72.2 & 52.3 \\
\hline & SS & 75.0 & 68.2 & 75.0 & 47.7 \\
\hline IDEXX & & 55.6 & 100 & 55.6 & 50.0 \\
\hline
\end{tabular}

a Comparative results obtained with serum samples from "Salmonella free hens" vs. samples from "infected hens".

b Comparative results obtained with serum samples from "Salmonella free hens + vaccinated hens" vs. samples from "infected hens".

Furthermore, when examined by IDEXX, serum samples in group $3(n=22)$ which were taken from vaccinated hens were all considered as $S$. enteritidis positive, while 18.2, 22.7, and $4.5 \%$ were positive when examined by indirect ELISA with the LPS, PS or SD antigens were used, respectively.

\subsection{Sensitivity and specificity of IDEXX and the indirect ELISA}

When the results of serum samples from salmonellae free hens and samples from infected hens were compared, the IDEXX sensitivity was found to be inferior $(55.6 \%)$ to that of indirect ELISA, with antigen PS showing the greatest sensitivity (76.4\%). On the other hand, the specificity of IDEXX and indirect ELISA based on LPS, PS or SD was $100 \%$ (Table III).

When serum samples of vaccinated hens were taken into account, in order to serologically differentiate field antibody responses from vaccinal ones (Table III), the sensitivity of IDEXX was again evidently lower than that of the indirect ELISA. In this comparison, the specificity of IDEXX was similar to that obtained with indirect ELISA based on LPS, SD or SS, with PS again yielding the best results (sensitivity $76.4 \%$, specificity $88.6 \%$ ).

\section{DISCUSSION}

These results showed that the indirect ELISA, based on LPS, PS or SD antigens, enables the identification of a greater number of infected birds and discriminates field antibody responses from the vaccinal ones better than the commercial IDEXX test. Overall, it is suggested that indirect ELISA based on the O-polysaccharide rich fraction (PS) could be used to confirm IDEXX results, especially when the differentiation of vaccinated birds is required.

In many control programs of microbial pathogens the development of serological screening tests for the discrimination of the vaccinated state from vaccine failure and natural infection is priority $[5,13,32]$. The use of vaccines in the control of Salmonella infections is gradually increasing [33] but conventional tests cannot discriminate vaccinal antibody responses from natural infection. This is one area where improvements are required, and more information is needed; obviously, further work needs to be done.

\section{ACKNOWLEDGMENTS}

This work was supported by grants from the "Departamento de Salud del Gobierno de Navarra", Spain (Grants \#1363-94, and \#530-97). 


\section{REFERENCES}

[1] Bailey J.S., Cox N.A., Blankenship L.C., Stern N.J., Hatchery contamination reduces the effectiveness of competitive exclusion treatments to control Salmonella colonisation of broiler chicks, Poultry Sci. 71 (1992) 6-12.

[2] Barrow P.A., Serological diagnosis of Salmonella serotype enteritidis infections in poultry by ELISA and other tests, Int. J. Food Microbiol. 21 (1994) 55-68.

[3] Barrow P., Serological diagnosis of Salmonella infection in poultry by ELISA with particular reference to $S$. enteritidis, in: Thorns C.J., Jones P. (Eds.), Monitoring procedures, rapid detection methods and techniques, Cost Action 97, European Commission, Brussels, 1997, pp. 47-59.

[4] Barrow P.A., Lovell M.A., Experimental infection of egg-laying hens with Salmonella enteritidis phage type 4, Avian Pathol. 20 (1991) 335-348.

[5] Bouma A., de Smit A.J., de Kluijver E.P., Terpstra, C., Moorman, R.J., Efficacy and stability of a subunit vaccine based on glycoprotein E2 of classical swine fever virus, Vet. Microbiol. 66 (1999) 101-114.

[6] Chart H., Rowe B., Baskerville A., Humphrey T.J., Serological analysis of chicken flocks for antibodies to Salmonella enteritidis, Vet. Rec. 127 (1990) 501-502.

[7] Chart H., Rowe B., Baskerville A., Humphrey T.J., Serological tests for Salmonella enteritidis in chickens, Vet. Rec. 126 (1990) 20-25.

[8] Chart H., Rowe B., Baskerville A., Humphrey T.J., Serological analysis for antibodies to S. enteritidis, Vet. Rec. 128 (1991) 215-221.

[9] Cooper G.L., Nicholas R.A., Bracewell C.D., Serological and bacteriological investigations of chickens from flocks naturally infected with Salmonella enteritidis, Vet. Rec. 125 (1989) 567572

[10] Dadrast H., Hesketh R., Taylor D.J., Egg yolk antibody detection in identification of Salmonella infected poultry, Vet. Rec. 126 (1990) 219-222.

[11] Davies R.H., Wray C., Guidelines on detection and monitoring of Salmonella infected poultry flocks with particular reference of Salmonella enteritidis, Report of a WHO consultation, WHO, Veterinary Public Health Unit, Graz, Austria, 1994.

[12] Desmidt M., Ducatelle R., Haesebrouck F., de Groot P.A., Verlinden M., Wijffels R., Hinton M., Bale J.A., Allen V.M., Detection of antibodies to Salmonella enteritidis in sera and yolks from experimentally and naturally infected chickens, Vet. Rec. 138 (1996) 223-226.

[13] Diaz R., Garatea P., Jones L.M., Moriyon I., Radial immunodiffusion test with a Brucella polysaccharide antigen for differentiating infected from vaccinated cattle, J. Clin. Microbiol. 10 (1979) 37-41.
[14] Furrer B., Baumgartner A., Bommeli W., Enzyme-linked immunosorbent assay (ELISA) for the detection of antibodies against Salmonella enteritidis in chicken blood or egg yolk, Zentralbl. Bakteriol. 279 (1993) 191-200.

[15] Gast R.K., Beard C.W., Serological detection of experimental Salmonella enteritidis infections in laying hens, Avian Dis. 34 (1990) 721-728.

[16] Humphrey T.J., Chart H., Baskerville A., Rowe B., The influence of age on the response of SPF hens to infection with Salmonella enteritidis PT4, Epidemiol. Infect. 106 (1991) 33-43.

[17] Kim C.J., Nagaraja K.V., Pomeroy B.S., Enzymelinked immunosorbent assay for the detection of Salmonella enteritidis infection in chickens, Am. J. Vet. Res. 52 (1991) 1069-1074.

[18] Lowry O.H., Rosebrough N., Farr A.L., Randall R.J., Protein measurement with the Folin phenol reagent, J. Biol. Chem. 193 (1951) 265-275.

[19] McIlroy S.G., McCracken R.M., Neill S.D., O'Brien J.J., Control, prevention and eradication of Salmonella enteritidis infection in broiler and broiler breeder flocks, Vet. Rec. 125 (1989) 545548.

[20] Nicholas R.A., Andrews S.J., Detection of antibody to Salmonella enteritidis and S. typhimurium in the yolk of hens' eggs, Vet. Rec. 128 (1991) 98100 .

[21] Nicholas R.A., Cullen G.A., Development and application of an ELISA for detecting antibodies to Salmonella enteritidis in chicken flocks, Vet. Rec. 128 (1991) 74-76.

[22] Osborn M.J., Studies on the Gram-negative bacterial cell wall. I. Evidence for the role of 2-keto3 deoxyoctonate in the lipopolysaccharide of Salmonella typhimurium, Proc. Natl. Acad. Sci. USA 50 (1963) 499-506.

[23] Shivaprasad H.L., Timoney J.F., Morales S., Lucio B., Baker R.C., Pathogenesis of Salmonella enteritidis infection in laying chickens. I. Studies on egg transmission, clinical signs, fecal shedding, and serologic responses, Avian Dis. 34 (1990) 548-557.

[24] Thorns C.J., Bell M.M., Sojka M.G., Nicholas R.A., Development and application of enzymelinked immunosorbent assay for specific detection of Salmonella enteritidis infections in chickens based on antibodies to SEF14 fimbrial antigen, J. Clin. Microbiol. 34 (1996) 792-797.

[25] Timoney J.F., Sikora N., Shivaprasad H.L., Opitz M., Detection of antibody to Salmonella enteritidis by a gm flagellin-based ELISA, Vet. Rec. 127 (1990) 168-169.

[26] Todd E.C., Epidemiology of foodborne diseases: a world-wide review, World Health Stat. Q. 50 (1997) 30-50.

[27] van Zijderveld F.G., van Zijderveld van Bemmel A.M., Anakotta J., Comparison of four different enzyme-linked immunosorbent assays for serological diagnosis of Salmonella enteritidis 
infections in experimentally infected chickens, J. Clin. Microbiol. 30 (1992) 2560-2566.

[28] van Zijderveld F.G., van Zijderveld van Bemmel A.M., Brouwers R.A., de Vries T.S., Landman W.J., de Jong W.A., Serological detection of chicken flocks naturally infected with Salmonella enteritidis, using an enzyme-linked immunosorbent assay based on monoclonal antibodies against the flagellar antigen, Vet. Q. 15 (1993) 135-137.

[29] Warren L., The thiobarbituric acid assay of sialic acids, J. Biol. Chem. 234 (1959) 1971-1975.

[30] Westphal O., Lüderitz O., Bister F., Über die Extraktion von Bakterien mit Phenol/Wasser, Z. Naturforsch. B 7 (1952) 148-155.
[31] Williams J.E., Whittemore A.D., Influence of age on the serological response of chickens to Salmonella typhimurium infection, Avian Dis. 19 (1975) 745-760.

[32] Zhang Y.Q., Mathiesen D., Kolbert C.P., Anderson J., Schoen R.T., Fikrig E., Persing D.H., Borrelia burgdorferi enzyme-linked immunosorbent assay for discrimination of OspA vaccination from spirochete infection, J. Clin. Microbiol. 35 (1997) 233-238.

[33] Zhang-Barber L., Turner A.K., Barrow P.A., Vaccination for control of Salmonella in poultry, Vaccine 17 (1999) 2538-2545. 